\title{
Alternative Erythropoietin Receptors in the Nervous System
}

\author{
Daniela Ostrowski ${ }^{1, *}$ and Ralf Heinrich ${ }^{2, *}$ \\ 1 Department of Biology, Truman State University, Kirksville, MO 63501, USA \\ 2 Department of Cellular Neurobiology, Institute for Zoology, Georg-August-University Göttingen, \\ 37073 Göttingen, Germany \\ * Correspondence: dostrowski@truman.edu (D.O.); rheinri1@gwdg.de (R.H.); \\ Tel.: +1-(660)-785-4408 (D.O); +49-(551)-39177958 (R.H.)
}

Received: 2 January 2018; Accepted: 26 January 2018; Published: 2 February 2018

\begin{abstract}
In addition to its regulatory function in the formation of red blood cells (erythropoiesis) in vertebrates, Erythropoietin (Epo) contributes to beneficial functions in a variety of non-hematopoietic tissues including the nervous system. Epo protects cells from apoptosis, reduces inflammatory responses and supports re-establishment of compromised functions by stimulating proliferation, migration and differentiation to compensate for lost or injured cells. Similar neuroprotective and regenerative functions of Epo have been described in the nervous systems of both vertebrates and invertebrates, indicating that tissue-protective Epo-like signaling has evolved prior to its erythropoietic function in the vertebrate lineage. Epo mediates its erythropoietic function through a homodimeric Epo receptor (EpoR) that is also widely expressed in the nervous system. However, identification of neuroprotective but non-erythropoietic Epo splice variants and Epo derivatives indicated the existence of other types of Epo receptors. In this review, we summarize evidence for potential Epo receptors that might mediate Epo's tissue-protective function in non-hematopoietic tissue, with focus on the nervous system. In particular, besides EpoR, we discuss three other potential neuroprotective Epo receptors: (1) a heteroreceptor consisting of EpoR and common beta receptor $(\beta c R),(2)$ the Ephrin (Eph) B4 receptor and (3) the human orphan cytokine receptor-like factor 3 (CRLF3).
\end{abstract}

Keywords: erythropoietin; non-hematopoietic functions; neuroprotection; regeneration; alternative erythropoietin receptors; common $\beta$ chain receptor; ephrin B4 receptor; cytokine receptor-like factor 3

\section{Introduction}

The helical cytokine erythropoietin (Epo) is an evolutionary ancient protein that is present in all major vertebrate lineages and can be synthesized by many cell types [1,2]. The name "erythropoietin" (first mentioned by Bonsdorff and Jalavisto [3]) arose from its functional implication in the generation of red blood cells (erythrocytes) to improve tissue oxygen supply, which was first described with some comprehensiveness by Erslev [4]. Cytokines typically mediate diverse responses in different tissues that may vary depending on their concentration, duration of exposure, developmental status and physiological context and may involve different types of receptors $[5,6]$. Beyond its role in erythropoiesis, numerous production sites, pleiotropic functions and diverse stimuli that induce Epo production were identified in mammalian and other vertebrate tissues, providing a basis for the hypothesis that Epo signaling originally evolved as a general mechanism to maintain or re-establish cellular functions under challenging physiological conditions, following injury and during pathogen invasion [7-11].

In addition to fetal liver and adult kidney, which in humans account for most of the circulating hormone, Epo is locally produced and released by cells of various tissues including heart, spleen, 
lung, testis, ovaries, retina and the nervous system (reviewed by: [12-15]). Within the nervous system, astrocytes, oligodendrocytes, neurons and endothelial cells may release Epo as a paracrine and/or autocrine signal (reviewed by [16]). Circulating, hormonal Epo is a four-helix glycoprotein consisting of 165 amino acids and several chains of carbohydrate residues that make up $\sim 40 \%$ of the mass of approximately $34 \mathrm{kDa}$. Mammalian brain-derived Epo has a lower content of sialic acid residues and brain-specific Epo splice variants have been detected in fish [17]. In addition to full length Epo, splice variants of human and murine Epo have been detected, among them the exon 3 deletion variant EV-3 present in human serum that lacks erythropoietic activity but protects various types of neurons from apoptotic cell death [18-20]. Similar to the production of circulating Epo (reviewed by [21]), hypoxia also increases Epo production and release in the nervous system, but various other challenges or insults have also been demonstrated to induce Epo in the nervous system, such as mechanical damage [22,23], infection [24], metabolic stress [25], elevated temperature [26], intense neural activity $[27,28]$ and enriched environment [29]. Prominent general functions of Epo in the nervous system and in other non-hematopoietic tissues are protection from apoptosis, reduction of inflammatory responses and re-establishment of compromised functions by support of proliferation, migration and differentiation to compensate for lost or injured cells [12]. Concerning the nervous system more specifically, Epo has been demonstrated to be crucial for normal brain development [30,31], to act neuroprotectively after hypoxic/ischemic insults and glutamate excitotoxicity [28,32], to suppress neuroinflammatory processes including activation of microglia $[33,34]$ and to promote regeneration after axonal damage [35-37]. Moreover, Epo enhanced cognitive performance and memory retrieval in healthy humans and patients affected by mood disorders or schizophrenia [38-43] paralleling experimental observations of wild type rodents, rodent models for neuropsychiatric diseases and diabetic mice [44-47]. Part of these effects on cognitive performance may result from Epo-induced increase of hippocampal pyramidal neurons and oligodendrocytes, which is only maintained when respective brain regions are sustainably challenged [48], and from Epo-mediated elevation of general motivation $[49,50]$.

It is meanwhile widely accepted that Epo mediates various beneficial effects on the development, maintenance and regeneration of nervous systems and options to use Epo or Epo derivatives for the treatment of neuropsychiatric and neurodegenerative diseases are being explored. In contrast, identification of the molecular nature of the involved Epo receptors has not been completed. A great number of (partially inconsistent) experimental results support the existence of a "tissue-protective" Epo receptor that differs from the homodimeric EpoR on erythroid progenitor cells. Since this proposed "tissue-protective" Epo receptor is not universally expressed in all cells that exhibit beneficial responses to Epo stimulation, other Epo-binding receptors must exist and expression of particular types of Epo receptors might generally depend on cell type, developmental stage and physiological context. This review summarizes evidence for the involvement of homodimeric EpoR and alternative Epo receptors as initiators of protective and regenerative mechanisms in non-hematopoietic tissues, with focus on the nervous system.

\section{Epo Function in Non-Hematopoietic Tissue Other Than the Nervous Tissue}

Besides the nervous system, Epo mediates a variety of functions in other non-hematopoietic tissues (reviewed by $[16,51,52])$. In the kidney interstitial fibroblasts produce and release hormonal Epo into the blood stream. However, human and rodent kidney also express EpoR, indicating an additional paracrine function of Epo [53]. Epo mediates a direct cell protective function following ischemia-reperfusion injury in rat kidneys $[54,55]$ and improves kidney function in a rat model for chronic kidney disease [56]. Epo also has a direct proliferative effect on mouse (not rat or human) myoblasts from skeletal muscle fibers and protects myoblasts against apoptosis in vitro [57]. In vivo studies using rodent models indicate that Epo-EpoR signaling can facilitate skeletal muscle repair following cardiotoxin-induced and mechanically induced muscle injuries [58,59]. In humans, improved motor function in Friedreich Ataxia patients following prolonged Epo administration 
has been reported [60]. Similar protective effects of Epo have been shown in animal models for ischemia-reperfusion injury of the heart [61,62] and for chronic heart failure [63], indicating a cardioprotective activity of Epo. The cardioprotective effect of Epo is mediated by a direct anti-apoptotic effect on cardiomyocytes as well as enhanced Epo-induced neovascularization due to the mobilization of endothelial progenitor cells from the bone marrow [63-66].

The angiogenic potential of Epo is also implied in other physiological processes and pathophysiological conditions. Epo is produced in cells of the uterus in an estrogen-dependent manner to promote blood vessel formation [67]. Epo promotes skin wound repair, especially in diabetic rodents and humans [68,69]. Besides angiogenesis, Epo exerts proliferative effect on numerous skin cell types, stimulates coagulation, reduces the inflammatory response, facilitates blood vessel regeneration, and enhances endothelial cell mitosis (reviewed by [70]). The role of Epo in tumor growth has been discussed as well, since many tumors express EpoR. Epo is widely used to treat anemia in patients undergoing chemotherapy [71] but its anti-apoptotic, proliferative and angiogenic effect might have a growth-promoting effect on cancer cells (reviewed by [72]). More recently the role of Epo-EpoR signaling in the regulation of energy metabolism has been described. Adipose tissue expresses EpoR and mice with selective EpoR knock out within adipose tissue show reduced total activity and develop obesity and insulin resistance $[2,15,73]$. The described functions of Epo in non-hematopoietic tissues could be mediated by both circulating Epo, predominantly produced by the kidney or other endocrinal organs, and tissue-derived, locally produced Epo.

\section{Homodimeric EpoR}

\subsection{Presence and Function of EpoR in the Mammalian Hematopoietic System}

Epo-EpoR signaling is the key regulator for the formation of mature erythrocytes (erythropoiesis) [21,74]. The adequate production of erythrocytes is important during all stages of life. Primitive erythrocytes are formed in yolk sac blood islands and express EpoR, from embryonic day 7.5 in mice and $\sim 16-20$ days of gestation in humans $[75,76]$. Although Epo is not crucial for the progress of differentiation of primitive erythroblasts, Epo supports their proliferation and survival $[75,76]$.

Later in development erythrocytes are continuously formed from pluripotent stem cells located in the fetal liver and adult human bone marrow and mice spleen (definitive erythropoiesis; reviewed by [77]). The maturation and differentiation of erythrocytes involves a stepwise differentiation process of hematopoietic progenitors that is controlled by the interplay of various cytokines, including Epo and e.g., stem cell factor (SCF) [78]. EpoR is expressed at low levels on burst-forming unit-erythroids (BFU-E) and its expression levels increases up to $10 \times$ on colony-forming unit-erythroids (CFU-E). Elevated expression of EpoR is mediated by transcription factors, such as GATA1, SCL/TAL1 and EKLF and Epo itself $[75,79]$. Epo and EpoR knock-out mice showed a complete impairment of erythropoiesis beyond the formation of CFU-E cells, indicating that Epo-EpoR signaling is crucial for cell survival and differentiation during this stage of erythropoiesis [80]. Later in erythropoiesis EpoR is downregulated and not required for cell survival.

\subsection{Molecular Characterization of EpoR}

EpoR expressed on the surface of immature erythroid cells is a member of the type I cytokine receptor family. In absence of the ligand, two receptor monomers form a disulfide-linked dimer that is integrated in the cell membrane. EpoR is comprised of an extracellular region, a single transmembrane domain, and an intracellular domain. The extracellular region consists of two domains (membrane-distal D1 and membrane-proximal D2) that provide two discrete binding sites for Epo. Initial binding of Epo to the high affinity site is followed by binding to the lower affinity site on the second monomer, which results in a conformational change of the dimeric EpoR [81,82]. Binding of Epo to both sites seems to be equally important for signal transduction, since mutation in one of the sites is sufficient to impair Epo-mediated signaling [82,83]. The first step of signal 
transduction following the conformational change of the receptor involves phosphorylation of several tyrosine residues within the membrane-distal portion of the intracellular domain. Since the receptor itself lacks kinase function, phosphorylation is mediated by a protein tyrosinase kinase (Jak2) that is constitutively associated with the receptor [84,85]. The main signal transducers for EpoR are signal transducer and activator of transcription factors (STAT) $5 \mathrm{~A}$ and $5 \mathrm{~B}$ that are activated within seconds after Epo binding [86,87]. STAT5A and STAT5B then accumulate in the nucleus and mediate Epo-responsive transcription of genes that control processes such as proliferation, apoptosis and cell differentiation. Other signaling pathways initiated by EpoR have also been reported, including the phosphoinositide-3-kinase (PI3K-AKT) and mitogen-activated protein kinase (Ras /MAPK) [88-92]. Negative feedback modulators from the suppressor of cytokine signaling family (SOCS) limit the function of EpoR signaling by acting on Jak2 and preventing STAT activation [93,94].

Key aspects of the hematopoietic EpoR structure and Epo-EpoR signaling are well conserved within vertebrates. The overall comparison of the zebrafish EpoR sequence to other vertebrates is relatively low (ranges from $44 \%$ to $27 \%$ ), however essential sites that are required for receptor dimerization, Epo binding, conformational changes and intracellular docking sites for downstream signaling molecules are conserved [95]. Cytokine-Jak-STAT signaling is an evolutionary ancient mechanism. The fruit fly Drosophila melanogaster contains a typical cytokine receptor (domeless) as well as Jak and STAT homologues (hopscotch, stat94/marelle) that share functional similarities to vertebrate type I cytokine receptor signaling [96,97]. However, orthologs of EpoR have not been identified in Drosophila or any other invertebrate species and Epo-mediated neuroprotection (which is absent in Drosophila but present in other insects (see below)) has to rely on other types of Epo-responsive receptors [98-100].

\subsection{Presence and Function of EpoR in the Nervous System}

Observations of increased apoptosis in non-hematopoietic tissue in Epo or EpoR knock-out mice prior to the onset of anemia implied a functional role of Epo-EpoR signaling beyond erythropoiesis [101,102]. EpoR is expressed in a temporal and cell-specific manner in the developing brain $[103,104]$, heart $[105,106]$, kidney [53,107], skeletal muscle [108] and endothelial cells [109,110]. In the mouse brain, EpoR is expressed in the neural tube (in radial glial cells) as early as E8 at levels comparable to adult hematopoietic tissue [104,111]. In the developing human embryo EpoR expression is first detected, as early as 7-8 weeks, in neurons and astrocytes of the spinal cord and brain $[103,112,113]$. EpoR knock-out mice show a reduced overall amount of neuronal progenitor cells and reduced neurogenesis [114] as well as developmental defects of the heart accompanied with a reduction in the number of cardiac myocytes and endothelial cells [101]. Based on these results, Epo-EpoR signaling was proposed to play a crucial role for the normal development of the brain and other organs. Since knock-out of Epo and EpoR genes result in severe anemia and premature death at E13.5, the role of Epo-EpoR signaling in non-hematopoietic tissue was difficult to study until Suzuki et al. [115] generated a transgene-rescue EpoR knock-out mouse that rescued EpoR expression exclusively in the hematopoietic lineage (hematopoietic-rescued EpoR knock-out). Hematopoietic-rescued EpoR knock-out mice displayed increased apoptosis but revealed no apparent abnormalities in the gross structure of the brain [102,115]. However, in a more detailed analysis Chen and colleagues [116] described a 2-fold increased apoptotic rate in the brains of hematopoietic-rescued adult EpoR knock-out mice and cultured hippocampal neurons showed poor survival in contrast to comparable cultures from wild type hippocampus. In addition, induced myocardial ischemia-reperfusion injury in the same transgenic mice resulted in a significantly larger infarct size and increased apoptosis in cardiomyocytes compared to wild-type mice [61]. The hypothesized anti-apoptotic function of Epo-EpoR signaling in non-hematopoietic tissue was supported by various in vitro studies. For example, undifferentiated human neuroblastoma cells express EpoR and Epo treatment prevents augmented apoptosis following the exposure to pro-apoptotic stimuli. Upon differentiation into neuron-like cells (induced by treatment of neuroblastoma cells with all-trans-retinoic acid) EpoR was downregulated and Epo no longer had an 
anti-apoptotic effect $[117,118]$. Besides the expression of EpoR in neurons, its mRNA is also detected in cultured oligodendrocytes and astrocytes, and administration of Epo enhances oligodendrocyte maturation and astrocyte proliferation [119]. Furthermore, direct dose-dependent effects of Epo on the proliferation and survival of other non-hematopoietic cells, including cultured primary mouse myoblasts from skeletal muscle [57] and human proximal tubular cells from the kidney [107] has been reported.

In adults, neurogenesis is limited to regions of the hippocampus and subventricular zone (SVZ). Impaired Epo-EpoR signaling significantly reduces adult neurogenesis [116] and Epo administration to normal C57BL/6 mice resulted in an increased number of neurons and oligodendrocytes [48]. Interestingly, newly formed cells resulted from enhanced differentiation of pre-existing precursor cells rather than from the formation of new cells due to cell proliferation. In addition, overexpression of constitutively active EpoR in pyramidal neurons of forebrain cortex and hippocampus can increase synaptic plasticity and enhances cognitive abilities and social memory [120].

EpoR expression in adult nervous systems remains very low under normal/healthy conditions, but various factors can modulate EpoR levels. For example, in healthy rodents, environmental enrichment, ambient heat or mild episodes of hypoxia can increase EpoR expression and furthermore protect neurons towards following injuries including severe ischemia $[25,26,29,121]$. Similar to the brain, EpoR expression in adult kidneys and hearts remains low, but increases following ischemic insult $[106,107]$. Although hypoxia-inducible factor (HIF) does not directly induce EpoR expression, factors such as pro-inflammatory cytokines and Epo itself have been identified to modulate EpoR expression in non-hematopoietic tissues. Induction of EpoR expression in non-hematopoietic tissues following injury has been correlated with the tissue protective effect of Epo administration in a variety of disease models, including stroke [122,123], traumatic brain injury [23,124], hypoxic ischemic encephalopathy (HIE) in neonates [125-127], peripheral nerve injury [128,129], ischemic reperfusion injury of the heart $[106,130]$ and kidney $[54,55]$ and chronic kidney disease [56]. However, promising results from animal model studies have only been partially transferred into successful clinical human trials [131-139]. Severity of the injury, different dosages and time points of Epo administration might influence the outcomes of the clinical trials. In addition, the protective effect of Epo can only manifest if there is an appropriate receptor expressed on the cell surface. Though neuroprotective and neuroregenerative functions have been described to depend on EpoR, most studies did not address the question whether homodimeric EpoR or a heteromeric receptor complex that includes EpoR as one component relayed the Epo signal in the responsive cells. Future studies with specific Epo-mimetic ligands will need to analyze the role of EpoR in Epo-mediated neuroprotection in more detail.

It should be noted that methodical shortcomings in the association of EpoR expression with beneficial functions in the nervous system have led to partially inconsistent results about the role of EpoR in nervous tissue. The methods that have been used to detect EpoR in non-hematopoietic tissue include the use of EpoR antibodies in tissue sections and western blots; whole mount in situ hybridization and quantitative analysis of EpoR mRNA levels in tissue samples and tissue specific analysis of EpoR transcripts in transgenic mice that express the human EpoR transcript. Commercially available EpoR antibodies showed non-specific cross-reactivity and results of studies solely based on the use of these antibodies were questioned [140-142]. A recent study by Ott et al. [143] characterized a new, highly specific, EpoR antibody directed against the cytoplasmic tail of human and murine EpoR. Results of the study show a specific EpoR expression in cultured primary murine brain cells, frozen brain sections of healthy young mice, and upregulation of EpoR in injured mice brains and patients suffering from epilepsy. Future studies using more specific antibodies against EpoR will need to validate EpoR expression within other non-hematopoietic tissues. However, the overall evidence that EpoR mRNA is expressed by cells other than the hematopoietic system, the protective effect of Epo following tissue injury and the detection of specific binding sites for Epo in the brain support the hypothesis that Epo-EpoR signaling is functional in non-hematopoietic tissues. 


\subsection{Functions of Alternative Versions of EpoR}

EpoR exists in three major isoforms that are generated by alternative splicing: full length protein as part of the functional receptor; a soluble protein that lacks the transmembrane and intracellular domains; and a truncated protein that lacks large parts of intracellular domains due to alternative splicing [144]. Some cells simultaneously express different isoforms of EpoR. The physiological role of both soluble and truncated EpoR has not been fully understood but both variants seem to be of functional importance.

Soluble EpoR (multiple variants may exist [8]) has been detected in various tissues including the brain [145]. Its presence in the blood is elevated by pro-inflammatory molecules [146] while its expression in the brain is downregulated (in contrast to full length EpoR) upon exposure to hypoxia [145]. Endothelial cells have been identified as one source of soluble EpoR within the mammalian brain [147]. Studies on the respiratory control system of mice indicated that the level of soluble EpoR, which captures Epo and prevents it from activating membrane-bound EpoR, regulates the sensitivity of Epo/EpoR signaling in the adaptation of ventilatory functions to different levels of oxygen [145]. Clearing of Epo from the circulation and extracellular space and regulating the availability of Epo for binding to membrane-bound Epo receptors seem to be the general function of soluble EpoR.

Truncated variants of EpoR have been identified in early-stage erythroid progenitor cells where they function as negative regulators of erythropoiesis $[148,149]$. Evidence for the function of truncated EpoR in the brain resulted from studies on substantia nigra dopaminergic neurons that co-express both, a full length EpoR and a truncated isoform that lacks large parts of EpoR's intracellular domains [150]. While expression of full length EpoR in HEK293T cells enabled Epo-stimulated phosphorylation of STAT5, expression of the truncated isoform did not confer any Epo-sensitivity, suggesting that truncated EpoR may not form Epo-responsive receptor molecules. Coexpression of the full length EpoR and the truncated EpoR isoform prevented Epo-stimulated STAT5 activation, indicating interference of the truncated receptor with EpoR-initiated transduction [150]. While the factors that regulate the levels of full length and truncated EpoR expression in dopaminergic neurons remain to be identified, the level of truncated EpoR expression seems to regulate the sensitivity of these cells to Epo.

\section{Alternative Epo-Receptors}

While Epo prevents apoptosis of erythroid progenitors by activating homodimeric EpoR, its protective functions in the nervous system and other non-hematopoietic tissues are also mediated by alternative receptors. Though Epo has a lower affinity to tissue-protective receptors than to homodimeric EpoR [7], brief access of the ligand is sufficient to induce neuroprotection $[7,28,151]$ while stimulation of erythropoiesis via homodimeric EpoR requires prolonged exposure to the ligand. This difference may result from different mechanisms to inactivate the respective Epo receptors or components of their downstream transduction pathways (summarized in [152]). A study with EpoR conditional knock-down mice by Tsai and co-workers reported persisting Epo-mediated neuroprotection during ischemia [114]. Existence of multiple, sometimes tissue-specific Epo splice variants suggests different functions that might be mediated by different receptors in different tissues $[19,153]$. As one example, the human splice variant EV-3 which lacks the entire third exon of the full-length Epo transcript does not activate homodimeric EpoR, and hence does not stimulate erythropoiesis, but mediates neuroprotection of rat hippocampal and insect neurons $[19,20]$. In addition to natural splice variants, various Epo-derivatives (e.g., carbamylated Epo, Epobis, helix B surface peptide) and molecules completely unrelated to the Epo peptide sequence (e.g., STS-E412) have been identified as non-erythropoietic but neuroprotective specific Epo mimetics [154-158]. Recent studies identified three candidate receptors that are expressed in the nervous system and mediate cell protective and regenerative functions upon binding of Epo and/or one of its non-hematopoietic agonists. 


\section{Common $\beta$ Chain Receptor}

Several studies (examples see below) indicated that a heteromeric complex consisting of one or more EpoR together with one or more molecules of the common beta receptor chain $(\beta c R)$ may serve as a tissue-protective Epo receptor.

$\beta c R$ (synonym CD131) is a member of the type I cytokine receptor subfamily, which forms heteromeric receptors with high-affinity receptor subunits for interleukin-3, interleukin-5 and granulocyte-macrophage colony-stimulating factor (GM-CSF) involved in particular regulatory mechanisms of hematopoiesis $[151,159,160]$. In these receptor complexes that include one "specific" and two $\beta c R$ subunits, $\beta c R$ is essential for receptor signaling, which is initiated by ligand-induced phosphorylation of its intracellular domains. Similarly (although stoichiometry may be different), $\beta \mathrm{cR}$ also associates with EpoR to form an Epo-sensitive tissue-protective heteroreceptor [6,7,154,161,162], which may already assemble in the absence of Epo ligand [163]. Co-expression of EpoR and $\beta c R$ has been detected in various cell types of the nervous system, the heart, the kidney and other organs (summarized in [144,157]) and Epo has been reported to induce tyrosine phosphorylation of $\beta c R$ [164]. Since both homodimeric EpoR and EpoR/ $\beta c R$ complexes activate Jak, downstream intracellular signaling pathways of both receptors are typically similar, though differences have been reported in a study on mouse primary neurons [165]. Like EpoR, large portions of $\beta c R$ are typically localized in intracellular compartments and their exposure at the cell surface is stimulated by physiological stressors such as hypoxia, metabolic deficiencies and inflammation $[165,166]$. Mechanisms that could regulate a preferential formation of homodimeric EpoR/EpoR versus formation of EpoR/ $\beta c R$ complexes from co-expressed subunits have not been characterized.

In the nervous system, cell types that can co-express EpoR and $\beta c R$ include neurons, astrocytes, microglia and vascular cells. Epo-mediated neuroprotection through $\mathrm{EpoR} / \beta c \mathrm{R}$ has been demonstrated in various studies $[158,162,167,168]$ including studies with $\beta c R$-deficient knock-out mice that lacked Epo-mediated neuroprotection [162] and relief of neuropathic pain [169]. In addition, Epo mediates cardio- and reno-protective effects through EpoR/ $\beta c R$-signaling in vitro and in vivo $[162,170]$. Selective activation of heteromeric EpoR/ $\beta c R$ but not of homodimeric EpoR has been demonstrated for CEpo [154], peptides derived from or related to helix-B of Epo [151,171] and several other ligands including mutant versions of Epo. Cells that co-express EpoR and $\beta c R$ should contain both heteromeric EpoR/ $\beta c R$ and homodimeric EpoR receptors. While Epo and other unselective ligands may induce activation of various transduction pathways starting from both types of receptors, ligands selective for heteromeric EpoR $/ \beta c R$ complexes may only evoke some portion of the response spectrum induced by Epo [167]. However, various brain regions and cell types that exhibit Epo-mediated protection do not co-express EpoR and $\beta c R$ in detectable amounts $[29,172,173]$ and other neuroprotective but non-erythropoietic signals (such as the Epo splice variant EV-3) have been demonstrated to bind neither homodimeric EpoR nor EpoR/ $\beta c R$ receptors [19]. This indicates that heteromeric EpoR/ $\beta c R$ (in addition to homodimeric EpoR) functions as a protective Epo receptor, at least in some types of neurons and glia and eventually depending on the type of physiological challenge, but certainly additional protective receptors exist in the mammalian nervous system.

\section{Ephrin B4 Receptor}

Ephrin receptors (Eph) represent the largest subfamily of receptor tyrosine kinases that typically mediate contact dependent cell-to-cell communication through interactions with membrane-bound ephrin ligands (reviewed by: [174,175]). Like Epo/EpoR signaling, ephrin/Eph signaling is involved in hematopoiesis, vascularization, cancer cell regulation and various functions in developing and mature nervous systems [176]. In the mammalian nervous system ephrins and Eph are expressed by neurons, astrocytes and endothelial cells [177-179]. Ephrin/Eph signaling regulates neurogenesis, axon growth, cell migration, synapse formation, dendritic spine morphology and synaptic plasticity underlying long-term changes of synaptic strength and memory formation [177,180-183]. Mammalian ephrins and Eph are divided in two classes A (6 A-ephrins and 9 EphA) and B (3 B-ephrins and 5 EphB) and 
within a class Eph typically can bind different ephrins ("promiscuous binding"). The stoichiometry of ephrin/Eph complexes seems to be variable. Preformed ephrin dimers and Eph dimers initially form heterotetramers which may associate to multimeric complexes whose particular composition can initiate specific responses in either one or both interacting cells (reviewed by [184]).

The EphB4 receptor differs from other Eph receptors by containing an isoleucine instead of a tyrosine at position 48 in the hydrophobic cavity. Since EphB4 has been demonstrated to interact rather specifically with ephrin-B2 [184] it might appear surprising, that just EphB4 also serves as a functional receptor for Epo [185]. Studies on ovarian carcinoma cells, that endogenously express both EphB4 and EpoR, demonstrated that both ephrin-B2 and Epo directly activate EphB4, causing increased proliferation and invasive migration mediated by Scr kinase (a cytosolic non-receptor tyrosine kinase) and STAT3 [185]. In contrast, EpoR activation in the same ovarian carcinoma cells leads to Jak activation and elevation of STAT5. Direct activation of EphB4 by Epo was further confirmed in EphB4-transfected COS-1 cells that did not express EpoR endogenously. Consequently, both ephrin-B2 and Epo independently activate EphB4 and may act synergistically when released onto the same target cells. Binding studies characterized EphB4 as a low affinity receptor for Epo with a KD of $880 \mathrm{nM}$ compared to a KD of $28 \mathrm{nM}$ for EpoR expressed in the same cells [185]. Effective activation of EphB4 may therefore critically depend on the relative abundance of EphB4 and EpoR on the cell surface (which is generally very low for EpoR in non-erythroid cells) and the sufficiency of short ligand exposure to activate downstream transduction mechanisms. However, data on both the surface expression of EphB4 and the time course of EphB4-initiated processes are not available. Moreover, survival of patients with breast and ovarian cancers was reduced with increased expression level of EphB4 but not of EpoR, and Epo treatment further reduced the survival chances of breast cancer patients with tumors that express high levels of EphB4 [185]. This indicated that Epo supported tumor growth particularly by activation of EphB4-initiated mechanisms.

EphB4 is expressed in the mammalian nervous system and ephrin-B2/EphB4 signaling has been demonstrated to regulate adult neurogenesis and its balance with gliogenesis in the subgranular zone of the hippocampus $[177,186]$. EphB4 expressed by neural stem cells is activated by direct contact with ephrin-B2 expressing astrocytes. This interaction stimulates self-renewal of and proliferation of neural stem cells and differentiation towards the neuronal lineage $[177,186]$. Indicating its role in synaptic function, ephrin-B2 knock-out in mouse hippocampus attenuated long term potentiation of synaptic transmission (LTP) following high-frequency synaptic activation [187]. Since Epo signaling in the brain has also been associated with neurogenesis and/or neuronal differentiation $[48,116,188]$ and increased cognitive performance $[42,120,189]$ it may well be that part of these processes are mediated via activation of EphB4 receptors. In addition, rat cortex neurons were demonstrated to co-express EpoR and EphB4 (as in the carcinoma cells described above) which probably enables differential cellular responses initiated by the two receptors that can both be activated by Epo [185].

\section{Cytokine Receptor-Like Factor 3 (CRLF3)}

Human CRLF3 (synonyms Crème9 and Cytor4; splice variants with minor differences) is an orphan cytokine receptor of unknown function that belongs to the subgroup of prototypic type 1 cytokine receptors which also includes EpoR, thrombopoietin receptor, prolactin receptor and growth hormone receptor [190]. The human CRLF3 gene is located on chromosome 17 and the protein is expressed in various normal tissues including the nervous system with higher expression levels in embryonic compared to adult brains. Additionally, some tumor cell lines and freshly isolated tumor tissues contain elevated levels of CRLF3 [191,192] Human CRLF3 includes 442 amino acids and contains a number of characteristic predicted domains. These include the conserved cytokine receptor motiv (WSXWS), a single-pass transmembrane sequence, and a docking site for Jak (NCBI GenBank NP_057070.3) [100,190] being consistent with reported activation of intracellular transduction pathways involving STAT3 [192]. 
Orthologs of human CRLF3 exist in other mammals, non-mammalian vertebrates (amphibia and fish), cephalochordates, tunicates and some insects including the beetle Tribolium castaneum, the locust Locusta migratoria and the cricket Gryllus bimaculatus but not the fruit fly Drosophila melanogaster ([98,101], unpublished own data). While EpoR orthologs are generally absent in insects and other invertebrates, the presence of CRLF3 in different insect species coincides with the presence of Epo-mediated neuroprotection and protective effects are absent in D. melanogaster $[10,98,100]$. Direct proof that CRLF3 represents a functional neuroprotective receptor for Epo was achieved by studies with primary brain cell cultures from T. castaneum [100]. In these neuron cultures, serum deprivation and hypoxia induce apoptotic cell death that can be completely prevented by both Epo and its non-erythropoietic splice variant EV-3. Knock-down of CRLF3 expression by double stranded RNA interference abolishes Epo's protective effects, indicating that CRLF3 functions as a neuroprotective receptor for Epo-like ligands in beetles [100]. Since direct binding of Epo and EV-3 to CRLF3 has not yet been confirmed, neuroprotective effects could also be mediated by a heteromeric receptor that contains CRLF3 as a crucial component for signal transduction. Epo-mediated neuroprotection of primary brain neurons from L. migratoria depends on Jak/STAT signal transduction [99], suggesting that insect CRLF3 activates similar intracellular pathways as its mammalian orthologs. Whether CRLF3 functions as a neuroprotective receptor for Epo and its non-erythropoietic splice variants in mammals including humans is under current investigation.

\section{Conclusions}

Endogenous Epo in the nervous system serves to adapt cells and neuronal circuits to physiological and pathological challenges ranging from normal activity-dependent mild reduction of oxygen availability and energy metabolites, via excitotoxicity to severe damage resulting from stroke, injury and inflammation. Numerous studies in humans and animals have documented Epo-mediated beneficial effects in the nervous system that secure cell survival, maintain functionality and support regeneration in deleterious physiological conditions. Epo-mediated mechanisms represent promising targets for pharmacological intervention with consequences of injury, neurodegenerative diseases and neuropsychiatric conditions. Besides homodimeric EpoR, $\beta c R /$ EpoR, EphB4 and CRLF3 (evidence summarized in Table 1), additional Epo-receptors might be expressed by particular cell types in particular physiological conditions. Hence, Epo and Epo-like ligands may activate different signal transduction cascades depending on their concentration (while low concentrations of Epo are beneficial, too high concentrations may be deleterious for the same cells) and on cell type, physiological condition and type of insult. Identification of Epo receptor molecules expressed by specific cells in particular situations may allow the development of Epo-mimetics that specifically interfere with one (or at least few) of the pleiotropic functions of Epo in- and outside the nervous system.

Table 1. Protective functions of classical EpoR and alternative Epo-receptors.

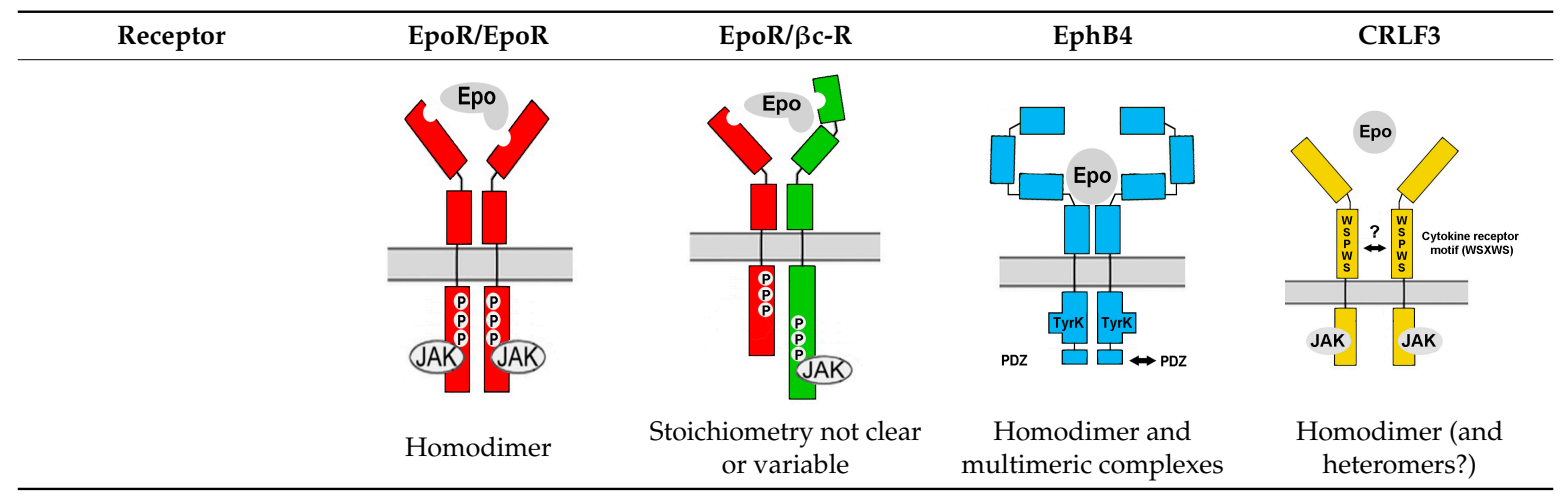


Table 1. Cont

\begin{tabular}{|c|c|c|c|c|}
\hline Receptor & EpoR/EpoR & EpoR/ $/ \beta c-R$ & EphB4 & CRLF3 \\
\hline $\begin{array}{l}\text { Transduction } \\
\text { pathways }\end{array}$ & $\begin{array}{c}\text { Jak, STAT5, PI3K/AKT, } \\
\text { Ras/MAPK, NF-кB } \\
\text { (not in erythroid cells) }\end{array}$ & $\begin{array}{l}\text { Jak, STAT5 } \\
\text { PI3K/AKT } \\
\text { MAPK }\end{array}$ & $\begin{array}{c}\text { Scr tyrosine kinase, } \\
\text { STAT3 }\end{array}$ & $\begin{array}{l}\text { Jak, STAT3, STAT } \\
\text { (insect) }\end{array}$ \\
\hline $\begin{array}{l}\text { Alternative ligands: } \\
\text { EV-3 } \\
\text { carbamylated Epo } \\
\text { helix b surface peptide }\end{array}$ & $\begin{array}{l}\text { No } \\
\text { No } \\
\text { No }\end{array}$ & $\begin{array}{l}\text { No [19] } \\
\text { Yes [193] } \\
\text { Yes [194] }\end{array}$ & No data available & $\begin{array}{c}\text { Yes [100] } \\
\text { No data available } \\
\text { Yes }^{*}\end{array}$ \\
\hline $\begin{array}{l}\text { Expression in the } \\
\text { nervous system }\end{array}$ & $\begin{array}{c}\text { Neurons [28,116,143], } \\
\text { Astrocytes [32,124,195], } \\
\text { Oligodendrocytes [143], } \\
\text { Microglia [143,195], } \\
\text { Endothelial } \\
\text { cells [32,110,143] }\end{array}$ & $\begin{array}{c}\text { Neurons [158,162,166], } \\
\text { Astrocytes [196], } \\
\text { Endothelial cells [197] }\end{array}$ & $\begin{array}{l}\text { Neural stem cells [177] } \\
\text { Hippocampal } \\
\text { neurons [187] } \\
\text { Endothelial cells [179] }\end{array}$ & Neurons (insect) ${ }^{*}$ \\
\hline $\begin{array}{l}\text { Epo-mediated effect } \\
\text { within the nervous } \\
\text { system }\end{array}$ & $\begin{array}{l}\text { Neuroprotection of } \\
\text { hippocampal } \\
\text { neurons [172] and } \\
\text { differentiated } \\
\text { neuroblastoma } \\
\text { cells [173] }\end{array}$ & $\begin{array}{l}\text { Neuroprotection of } \\
\text { rodent motor } \\
\text { neurons [193] and } \\
\text { spinal cord } \\
\text { neurons [198]; } \\
\text { Reduction of } \\
\text { neuropathic pain in } \\
\text { mice [169] }\end{array}$ & No data available & $\begin{array}{l}\text { Neuroprotection of } \\
\text { insect brain } \\
\text { neurons [100]; } \\
\text { Regeneration of insect } \\
\text { auditory receptor } \\
\text { fibers and neurites of } \\
\text { cultured insect } \\
\text { neurons * }\end{array}$ \\
\hline
\end{tabular}

Acknowledgments: We acknowledge the support of the Department of Biology at Truman State University for providing partial funding toward the completion of this work.

Conflicts of Interest: The authors declare no conflict of interest.

\section{References}

1. Nogawa-Kosaka, N.; Hirose, T.; Kosaka, N.; Aizawa, Y.; Nagasawa, K.; Uehara, N.; Miyazaki, H.; Komatsu, N.; Kato, T. Structural and biological properties of erythropoietin in Xenopus laevis. Exp. Hematol. 2010, 38, 363-372. [CrossRef] [PubMed]

2. Zhang, Y.; Wang, L.; Dey, S.; Alnaeeli, M.; Suresh, S.; Rogers, H.; Teng, R.; Noguchi, C.T. Erythropoietin action in stress response, tissue maintenance and metabolism. Int. J. Mol. Sci. 2014, 15, 10296-10333. [CrossRef] [PubMed]

3. Bonsdorff, E.; Jalavisto, E. A Humoral Mechanism in Anoxic Erythrocytosis. Acta Physiol. Scand. 1948, 16, 150-170. [CrossRef]

4. Erslev, A. Humoral Regulation of Red Cell Production. Blood 1953, 8, 349-357. [PubMed]

5. Dinarello, C.A. Historical insights into cytokines. Eur. J. Immunol. 2007, 37, 34-45. [CrossRef] [PubMed]

6. Cendrowski, J.; Mamińska, A.; Miaczynska, M. Endocytic regulation of cytokine receptor signaling. Cytokine Growth Factor Rev. 2016, 32, 63-73. [CrossRef] [PubMed]

7. Brines, M.; Cerami, A. Emerging biological roles for erythropoietin in the nervous system. Nat. Rev. Neurosci. 2005, 6, 484. [CrossRef] [PubMed]

8. Arcasoy, M.O. The non-haematopoietic biological effects of erythropoietin. Br. J. Haematol. 2008, 141, $14-31$. [CrossRef] [PubMed] 
9. Ghezzi, P.; Conklin, D. Tissue-Protective Cytokines; Ghezzi, P., Cerami, A., Eds.; Methods in Molecular Biology; Humana Press: Totowa, NJ, USA, 2013; Volume 982, ISBN 978-1-62703-307-7.

10. Heinrich, R.; Günther, V.; Miljus, N. Erythropoietin-Mediated Neuroprotection in Insects Suggests a Prevertebrate Evolution of Erythropoietin-Like Signaling. Vitam. Horm. 2017, 105, 181-196. [CrossRef] [PubMed]

11. Juul, S.; Felderhoff-Mueser, U. Epo and other hematopoietic factors. Semin. Fetal Neonatal Med. 2007, 12, 250-258. [CrossRef] [PubMed]

12. Chateauvieux, S.; Grigorakaki, C.; Morceau, F.; Dicato, M.; Diederich, M. Erythropoietin, erythropoiesis and beyond. Biochem. Pharmacol. 2011, 82, 1291-1303. [CrossRef] [PubMed]

13. Ghezzi, P.; Brines, M. Erythropoietin as an antiapoptotic, tissue-protective cytokine. Cell Death Differ. 2004, 11 (Suppl. 1), S37-S44. [CrossRef] [PubMed]

14. Fandrey, J. Oxygen-dependent and tissue-specific regulation of erythropoietin gene expression. Am. J. Physiol. Regul. Integr. Comp. Physiol. 2004, 286, R977-R988. [CrossRef] [PubMed]

15. Wang, L.; Di, L.; Noguchi, C.T. Erythropoietin, a novel versatile player regulating energy metabolism beyond the erythroid system. Int. J. Biol. Sci. 2014, 10, 921-939. [CrossRef] [PubMed]

16. Ogunshola, O.O.; Bogdanova, A.Y. Epo and Non-hematopoietic Cells: What Do We Know? In Tissue-Protective Cytokines: Methods and Protocols (Methods in Molecular Biology); Ghezzi, P., Cerami, A., Eds.; Methods in Molecular Biology; Humana Press: Totowa, NJ, USA, 2013; Volume 982, pp. 13-41, ISBN 978-1-62703-307-7.

17. Chou, C.F.; Tohari, S.; Brenner, S.; Venkatesh, B. Erythropoietin gene from a teleost fish, Fugu rubripes. Blood 2004, 104, 1498-1503. [CrossRef] [PubMed]

18. Bonnas, C.B. Identification of Erythropoietin Isoforms and Evaluation of Their Biological Importance. Ph.D. Dissertation, Medizinischen Fakultät Charité-Universitätsmedizin Berlin, Berlin, Germany, 14 June 2009.

19. Bonnas, C.; Wüstefeld, L.; Winkler, D.; Kronstein-Wiedemann, R.; Dere, E.; Specht, K.; Boxberg, M.; Tonn, T.; Ehrenreich, H.; Stadler, H.; et al. EV-3, an endogenous human erythropoietin isoform with distinct functional relevance. Sci. Rep. 2017, 7, 1-15. [CrossRef] [PubMed]

20. Miljus, N.; Massih, B.; Weis, M.A.; Rison, J.V.; Bonnas, C.B.; Sillaber, I.; Ehrenreich, H.; Geurten, B.R.H.; Heinrich, R. Neuroprotection and endocytosis: Erythropoietin receptors in insect nervous systems. J. Neurochem. 2017, 141, 63-74. [CrossRef] [PubMed]

21. Jelkmann, W. Regulation of erythropoietin production. J. Physiol. 2011, 589, 1251-1258. [CrossRef] [PubMed]

22. Campana, W.M.; Myers, R.R. Exogenous erythropoietin protects against dorsal root ganglion apoptosis and pain following peripheral nerve injury. Eur. J. Neurosci. 2003, 18, 1497-1506. [CrossRef] [PubMed]

23. Lu, D.; Mahmood, A.; Qu, C.; Goussev, A.; Schallert, T.; Chopp, M. Erythropoietin enhances neurogenesis and restores spatial memory in rats after traumatic brain injury. J. Neurotrauma 2005, 22, 1011-1017. [CrossRef] [PubMed]

24. Shen, Y.; Yu, H.-M.; Yuan, T.-M.; Gu, W.-Z.; Wu, Y.-D. Erythropoietin attenuates white matter damage, proinflammatory cytokine and chemokine induction in developing rat brain after intra-uterine infection. Neuropathology 2009, 29, 528-535. [CrossRef] [PubMed]

25. Siren, A.-L.; Fratelli, M.; Brines, M.; Goemans, C.; Casagrande, S.; Lewczuk, P.; Keenan, S.; Gleiter, C.; Pasquali, C.; Capobianco, A.; et al. Erythropoietin prevents neuronal apoptosis after cerebral ischemia and metabolic stress. Proc. Natl. Acad. Sci. USA 2001, 98, 4044-4049. [CrossRef] [PubMed]

26. Shein, N.A.; Horowitz, M.; Alexandrovich, A.G.; Tsenter, J.; Shohami, E. Heat Acclimation Increases Hypoxia-Inducible Factor $1 \alpha$ and Erythropoietin Receptor Expression: Implication for Neuroprotection after Closed Head Injury in Mice. J. Cereb. Blood Flow Metab. 2005, 25, 1456-1465. [CrossRef] [PubMed]

27. Calapai, G.; Marciano, M.C.; Corica, F.; Allegra, A.; Parisi, A.; Frisina, N.; Caputi, A.P.; Buemi, M. Erythropoietin protects against brain ischemic injury by inhibition of nitric oxide formation. Eur. J. Pharmacol. 2000, 401, 349-356. [CrossRef]

28. Morishita, E.; Masuda, S.; Nagao, M.; Yasuda, Y.; Sasaki, R. Erythropoetin receptor is expressed in rat hippocampal and cerebral cortical neurons, and erythropoietin prevents in vitro glutamate-induced neuronal death. Neuroscience 1996, 76, 105-116. [CrossRef]

29. Sanchez, P.E.; Fares, R.P.; Risso, J.-J.; Bonnet, C.; Bouvard, S.; Le-Cavorsin, M.; Georges, B.; Moulin, C.; Belmeguenai, A.; Bodennec, J.; et al. Optimal neuroprotection by erythropoietin requires elevated expression of its receptor in neurons. Proc. Natl. Acad. Sci. USA 2009, 106, 9848-9853. [CrossRef] [PubMed] 
30. Yu, X.; Shacka, J.J.; Eells, J.B.; Suarez-Quian, C.; Przygodzki, R.M.; Beleslin-Cokic, B.; Lin, C.-S.; Nikodem, V.M.; Hempstead, B.; Flanders, K.C.; et al. Erythropoietin receptor signaling is required for normal brain development. Development 2002, 129, 505-516. [PubMed]

31. Genc, S.; Koroglu, T.F.; Genc, K. Erythropoietin as a novel neuroprotectant. Restor. Neurol. Neurosci. 2004, 22, 105-119. [CrossRef] [PubMed]

32. Bernaudin, M.; Marti, H.H.; Roussel, S.; Divoux, D.; Nouvelot, A.; MacKenzie, E.T.; Petit, E. A potential role for erythropoietin in focal permanent cerebral ischemia in mice. J. Cereb. Blood Flow Metab. 1999, 19, 643-651. [CrossRef] [PubMed]

33. Bond, W.S.; Rex, T.S. Evidence that erythropoietin modulates neuroinflammation through differential action on neurons, astrocytes, and microglia. Front. Immunol. 2014, 5, 1-8. [CrossRef] [PubMed]

34. Mitkovski, M.; Dahm, L.; Heinrich, R.; Monnheimer, M.; Gerhart, S.; Stegmüller, J.; Hanisch, U.K.; Nave, K.A.; Ehrenreich, H. Erythropoietin dampens injury-induced microglial motility. J. Cereb. Blood Flow Metab. 2015, 35, 1233-1236. [CrossRef] [PubMed]

35. Kretz, A.; Happold, C.J.; Marticke, J.K.; Isenmann, S. Erythropoietin promotes regeneration of adult CNS neurons via Jak2/Stat3 and PI3K/AKT pathway activation. Mol. Cell. Neurosci. 2005, 29, 569-579. [CrossRef] [PubMed]

36. Zhang, W.; Sun, B.; Yu, Z.; An, J.; Liu, Q.; Ren, T. High dose erythropoietin promotes functional recovery of rats following facial nerve crush. J. Clin. Neurosci. 2009, 16, 554-556. [CrossRef] [PubMed]

37. Yin, Z.S.; Zhang, H.; Gao, W. Erythropoietin Promotes Functional Recovery and Enhances Nerve Regeneration after Peripheral Nerve Injury in Rats. Am. J. Neuroradiol. 2010, 31, 509-515. [CrossRef] [PubMed]

38. Miskowiak, K.; Inkster, B.; O'Sullivan, U.; Selvaraj, S.; Goodwin, G.M.; Harmer, C.J. Differential effects of erythropoietin on neural and cognitive measures of executive function 3 and 7 days post-administration. Exp. Brain Res. 2008, 184, 313-321. [CrossRef] [PubMed]

39. Miskowiak, K.; O'Sullivan, U.; Harmer, C.J. Erythropoietin Reduces Neural and Cognitive Processing of Fear in Human Models of Antidepressant Drug Action. Biol. Psychiatry 2007, 62, 1244-1250. [CrossRef] [PubMed]

40. Ehrenreich, H.; Hinze-Selch, D.; Stawicki, S.; Aust, C.; Knolle-Veentjer, S.; Wilms, S.; Heinz, G.; Erdag, S.; Jahn, H.; Degner, D.; et al. Improvement of cognitive functions in chronic schizophrenic patients by recombinant human erythropoietin. Mol. Psychiatry 2007, 12, 206-220. [CrossRef] [PubMed]

41. Kastner, A.; Grube, S.; El-Kordi, A.; Stepniak, B.; Friedrichs, H.; Sargin, D.; Schwitulla, J.; Begemann, M.; Giegling, I.; Miskowiak, K.W.; et al. Common Variants of the Genes Encoding Erythropoietin and Its Receptor Modulate Cognitive Performance in Schizophrenia. Mol. Med. 2012, 18, 1029-1040. [CrossRef] [PubMed]

42. Miskowiak, K.; O’Sullivan, U.; Harmer, C.J. Erythropoietin Enhances Hippocampal Response during Memory Retrieval in Humans. J. Neurosci. 2007, 27, 2788-2792. [CrossRef] [PubMed]

43. Miskowiak, K.W.; John Rush, A.; Gerds, T.A.; Vinberg, M.; Kessing, L.V. Targeting treatments to improve cognitive function in mood disorder: Suggestions from trials using erythropoietin. J. Clin. Psychiatry 2016, 77, e1639-e1646. [CrossRef] [PubMed]

44. Sadamoto, Y.; Igase, K.; Sakanaka, M.; Sato, K.; Otsuka, H.; Sakaki, S.; Masuda, S.; Sasaki, R. Erythropoietin prevents place navigation disability and cortical infarction in rats with permanent occlusion of the middle cerebral artery. Biochem. Biophys. Res. Commun. 1998, 253, 26-32. [CrossRef] [PubMed]

45. Ehrenreich, H.; Aust, C.; Krampe, H.; Jahn, H.; Jacob, S.; Herrmann, M.; Sirén, A.L. Erythropoietin: Novel approaches to neuroprotection in human brain disease. Metab. Brain Dis. 2004, 19, 195-206. [CrossRef] [PubMed]

46. El-Kordi, A.; Radyushkin, K.; Ehrenreich, H. Erythropoietin improves operant conditioning and stability of cognitive performance in mice. BMC Biol. 2009, 7, 37. [CrossRef] [PubMed]

47. Wang, M.; Yan, W.; Liu, Y.; Hu, H.; Sun, Q.; Chen, X.; Zang, W.; Chen, L. Erythropoietin ameliorates diabetes-associated cognitive dysfunction in vitro and in vivo. Sci. Rep. 2017, 7, 1-11. [CrossRef] [PubMed]

48. Hassouna, I.; Ott, C.; Wüstefeld, L.; Offen, N.; Neher, R.A.; Mitkovski, M.; Winkler, D.; Sperling, S.; Fries, L.; Goebbels, S.; et al. Revisiting adult neurogenesis and the role of erythropoietin for neuronal and oligodendroglial differentiation in the hippocampus. Mol. Psychiatry 2016, 21, 1752-1767. [CrossRef] [PubMed]

49. Ninot, G.; Connes, P.; Caillaud, C. Effects of recombinant human erythropoietin injections on physical self in endurance athletes. J. Sports Sci. 2006, 24, 383-391. [CrossRef] [PubMed] 
50. Schuler, B.; Vogel, J.; Grenacher, B.; Jacobs, R.A.; Arras, M.; Gassmann, M. Acute and chronic elevation of erythropoietin in the brain improves exercise performance in mice without inducing erythropoiesis. FASEB J. 2012, 26, 3884-3890. [CrossRef] [PubMed]

51. Noguchi, C.T.; Wang, L.; Rogers, H.M.; Teng, R.; Jia, Y. Survival and proliferative roles of erythropoietin beyond the erythroid lineage. Expert Rev. Mol. Med. 2008, 10, e36. [CrossRef] [PubMed]

52. Brines, M.; Cerami, A. Discovering erythropoietin's extra-hematopoietic functions: Biology and clinical promise. Kidney Int. 2006, 70, 246-250. [CrossRef] [PubMed]

53. Echigoya, M.H.; Obikane, K.; Nakashima, T.; Sasaki, S. Glomerular localization of erythropoietin receptor mRNA and protein in neonatal and mature mouse kidney. Nephron. Exp. Nephrol. 2005, 100, 21-29. [CrossRef] [PubMed]

54. Ardalan, M.R.; Estakhri, R.; Hajipour, B.; Ansarin, K.; Asl, N.A.; Nasirizade, M.R.; Azar, A.N.; Ghorbanihaghjou, A.; Vatankhah, A.M.; Esmaili, H.A. Erythropoietin ameliorates oxidative stress and tissue injury following renal ischemia/reperfusion in rat kidney and lung. Med. Princ. Pract. 2012, 22, 70-74. [CrossRef] [PubMed]

55. Zou, Y.R.; Zhang, J.; Wang, J.; Peng, L.; Li, G.S.; Wang, L. Erythropoietin Receptor Activation Protects the Kidney From Ischemia/Reperfusion-Induced Apoptosis by Activating ERK/p53 Signal Pathway. Transplant. Proc. 2016, 48, 217-221. [CrossRef] [PubMed]

56. Garrido, P.; Ribeiro, S.; Fernandes, J.; Vala, H.; Rocha-Pereira, P.; Bronze-da-Rocha, E.; Belo, L.; Costa, E.; Santos-Silva, A.; Reis, F. Resistance to recombinant human erythropoietin therapy in a rat model of chronic kidney disease associated anemia. Int. J. Mol. Sci. 2016, 17, 28. [CrossRef] [PubMed]

57. Ogilvie, M.; Yu, X.; Nicolas-Metral, V.; Pulido, S.M.; Liu, C.; Ruegg, U.T.; Noguchi, C.T. Erythropoietin stimulates proliferation and interferes with differentiation of myoblasts. J. Biol. Chem. 2000, 275, 39754-39761. [CrossRef] [PubMed]

58. Jia, Y.; Suzuki, N.; Yamamoto, M.; Gassmann, M.; Noguchi, C.T. Endogenous erythropoietin signaling facilitates skeletal muscle repair and recovery following pharmacologically induced damage. FASEB J. 2012, 26, 2847-2858. [CrossRef] [PubMed]

59. Rotter, R.; Menshykova, M.; Winkler, T.; Matziolis, G.; Stratos, I.; Schoen, M.; Bittorf, T.; Mittlmeier, T.; Vollmar, B. Erythropoietin improves functional and histological recovery of traumatized skeletal muscle tissue. J. Orthop. Res. 2008, 26, 1618-1626. [CrossRef] [PubMed]

60. Nachbauer, W.; Boesch, S.; Reindl, M.; Eigentler, A.; Hufler, K.; Poewe, W.; Löscher, W.; Wanschitz, J. Skeletal Muscle Involvement in Friedreich Ataxia and Potential Effects of Recombinant Human Erythropoietin Administration on Muscle Regeneration and Neovascularization. J. Neuropathol. Exp. Neurol. 2012, 71, 708-715. [CrossRef] [PubMed]

61. Tada, H.; Kagaya, Y.; Takeda, M.; Ohta, J.; Asaumi, Y.; Satoh, K.; Ito, K.; Karibe, A.; Shirato, K.; Minegishi, N.; et al. Endogenous erythropoietin system in non-hematopoietic lineage cells plays a protective role in myocardial ischemia/reperfusion. Cardiovasc. Res. 2006, 71, 466-477. [CrossRef] [PubMed]

62. Calvillo, L.; Latini, R.; Kajstura, J.; Leri, A.; Anversa, P.; Ghezzi, P.; Salio, M.; Cerami, A.; Brines, M. Recombinant human erythropoietin protects the myocardium from ischemia-reperfusion injury and promotes beneficial remodeling. Proc. Natl. Acad. Sci. USA. 2003, 100, 4802-4806. [CrossRef] [PubMed]

63. Westenbrink, B.D.; Lipšic, E.; Van Der Meer, P.; Van Der Harst, P.; Oeseburg, H.; Du Marchie Sarvaas, G.J.; Koster, J.; Voors, A.A.; Van Veldhuisen, D.J.; Van Gilst, W.H.; et al. Erythropoietin improves cardiac function through endothelial progenitor cell and vascular endothelial growth factor mediated neovascularization. Eur. Heart J. 2007, 28, 2018-2027. [CrossRef] [PubMed]

64. Burger, D.; Lei, M.; Geoghegan-Morphet, N.; Lu, X.; Xenocostas, A.; Feng, Q. Erythropoietin protects cardiomyocytes from apoptosis via up-regulation of endothelial nitric oxide synthase. Cardiovasc. Res. 2006, 72, 51-59. [CrossRef] [PubMed]

65. Narmoneva, D.A.; Vukmirovic, R.; Davis, M.E.; Kamm, R.D.; Lee, R.T. Endothelial cells promote cardiac myocyte survival and spatial reorganization: Implications for cardiac regeneration. Circulation 2004, 110, 962-968. [CrossRef] [PubMed]

66. Heeschen, C.; Aicher, A.; Lehmann, R.; Fichtlscherer, S.; Vasa, M.; Urbich, C.; Mildner-Rihm, C.; Martin, H.; Zeiher, A.M.; Dimmeler, S. Erythropoietin is a potent physiological stimulus for endothelial progenitor cell mobilization. Blood 2003, 102, 1340-1346. [CrossRef] [PubMed] 
67. Yasuda, Y.; Masuda, S.; Chikuma, M.; Inoue, K.; Nagao, M.; Sasaki, R. Estrogen-dependent production of erythropoietin in uterus and its implication in uterine angiogenesis. J. Biol. Chem. 1998, 273, 25381-25387. [CrossRef] [PubMed]

68. Bader, A.; Lorenz, K.; Richter, A.; Scheffler, K.; Kern, L.; Ebert, S.; Giri, S.; Behrens, M.; Dornseifer, U.; Macchiarini, P.; et al. Interactive Role of Trauma Cytokines and Erythropoietin and Their Therapeutic Potential for Acute and Chronic Wounds. Rejuvenation Res. 2011, 14, 57-66. [CrossRef] [PubMed]

69. Hamed, S.; Ullmann, Y.; Masoud, M.; Hellou, E.; Khamaysi, Z.; Teot, L. Topical erythropoietin promotes wound repair in diabetic rats. J. Investig. Dermatol. 2010, 130, 287-294. [CrossRef] [PubMed]

70. Hamed, S.; Bennett, C.L.; Demiot, C.; Ullmann, Y.; Teot, L.; Desmoulière, A. Erythropoietin, a novel repurposed drug: An innovative treatment for wound healing in patients with diabetes mellitus. Wound Repair Regen. 2014, 22, 23-33. [CrossRef] [PubMed]

71. Del Mastro, L.; Venturini, M.; Lionetto, R.; Garrone, O.; Melioli, G.; Pasquetti, W.; Sertoli, M.R.; Bertelli, G.; Canavese, G.; Costantini, M.; et al. Randomized phase III trial evaluating the role of erythropoietin in the prevention of chemotherapy-induced anemia. J. Clin. Oncol. 1997, 15, 2715-2721. [CrossRef] [PubMed]

72. Szenajch, J.; Wcislo, G.; Jeong, J.Y.; Szczylik, C.; Feldman, L. The role of erythropoietin and its receptor in growth, survival and therapeutic response of human tumor cells. From clinic to bench-A critical review. Biochim. Biophys. Acta Rev. Cancer 2010, 1806, 82-95. [CrossRef] [PubMed]

73. Teng, R.; Gavrilova, O.; Suzuki, N.; Chanturiya, T.; Schimel, D.; Hugendubler, L.; Mammen, S.; Yver, D.R.; Cushman, S.W.; Yamamoto, M.; et al. Disrupted erythropoietin signaling promotes obesity and alters hypothalamus proopiomelanocortin production. Nat. Commun. 2013, 2, 1-24. [CrossRef]

74. Dzierzak, E.; Philipsen, S. Erythropoiesis: Development and differentiation. Cold Spring Harb. Perspect. Med. 2013, 3, 1-16. [CrossRef] [PubMed]

75. Lin, C.S.; Lim, S.K.; D’Agati, V.; Costantini, F. Differential effects of an erythropoietin receptor gene disruption on primitive and definitive erythropoiesis. Genes Dev. 1996, 10, 154-164. [CrossRef] [PubMed]

76. Malik, J.; Kim, A.R.; Tyre, K.A.; Cherukuri, A.R.; Palis, J. Erythropoietin critically regulates the terminal maturation of murine and human primitive erythroblasts. Haematologica 2013, 98, 1778-1787. [CrossRef] [PubMed]

77. Palis, J. Primitive and definitive erythropoiesis in mammals. Front. Physiol. 2014, 5 JAN, 1-9. [CrossRef] [PubMed]

78. Wu, H.; Klingmüller, U.; Acurio, A.; Hsiao, J.G.; Lodish, H.F. Functional interaction of erythropoietin and stem cell factor receptors is essential for erythroid colony formation. Proc. Natl. Acad. Sci. USA 1997, 94, 1806-1810. [CrossRef] [PubMed]

79. Rogers, H.M.; Yu, X.; Wen, J.; Smith, R.; Fibach, E.; Noguchi, C.T. Hypoxia alters progression of the erythroid program. Exp. Hematol. 2008, 36, 17-27. [CrossRef] [PubMed]

80. Wu, H.; Liu, X.; Jaenisch, R.; Lodish, H.F. Generation of committed erythroid BFU-E and CFU-E progenitors does not require erythropoietin or the erythropoietin receptor. Cell 1995, 83, 59-67. [CrossRef]

81. Syed, R.S.; Reid, S.W.; Li, C.; Cheetham, J.C.; Aoki, K.H.; Liu, B.; Zhan, H.; Osslund, T.D.; Chirino, A.J.; Zhang, J.; et al. Efficiency of signaling through cytokine receptors depens critically on receptor orientation. Nature 1998, 395, 511-516. [CrossRef] [PubMed]

82. Matthews, D.J.; Topping, R.S.; Cass, R.T.; Giebel, L.B. A sequential dimerization mechanism for erythropoietin receptor activation. Proc. Natl. Acad. Sci. USA 1996, 93, 9471-9476. [CrossRef] [PubMed]

83. Zhang, Y.L.; Radhakrishnan, M.L.; Lu, X.; Gross, A.W.; Tidor, B.; Lodish, H.F. Symmetric Signaling by an Asymmetric 1 Erythropoietin: 2 Erythropoietin Receptor Complex. Mol. Cell 2009, 33, 266-274. [CrossRef] [PubMed]

84. Witthuhn, B.A.; Quelle, F.W.; Silvennoinen, O.; Yi, T.; Tang, B.; Miura, O.; Ihle, J.N. JAK2 associates with the erythropoietin receptor and is tyrosine phosphorylated and activated following stimulation with erythropoietin. Cell 1993, 74, 227-236. [CrossRef]

85. Miura, O.; Nakamura, N.; Quelle, F.W.; Witthuhn, B.A.; Ihle, J.N.; Aoki, N. Erythropoietin induces association of the JAK2 protein tyrosine kinase with the erythropoietin receptor in vivo. Blood 1994, 84, 1501-1507. [CrossRef] [PubMed]

86. Klingmüller, U.; Bergelson, S.; Hsiao, J.G.; Lodish, H.F. Multiple tyrosine residues in the cytosolic domain of the erythropoietin receptor promote activation of STAT5. Proc. Natl. Acad. Sci. USA 1996, 93, 8324-8328. [CrossRef] [PubMed] 
87. Grebien, F.; Kerenyi, M.A.; Kovacic, B.; Kolbe, T.; Becker, V.; Dolznig, H.; Pfeffer, K.; Klingmüller, U.; Müller, M.; Beug, H.; et al. Stat5 activation enables erythropoiesis in the absence of EpoR and Jak2. Blood 2008, 111, 4511-4522. [CrossRef] [PubMed]

88. Myklebust, J.H.; Blomhoff, H.K.; Rusten, L.S.; Stokke, T.; Smeland, E.B. Activation of phosphatidylinositol 3-kinase is important for erythropoietin-induced erythropoiesis from CD34(+) hematopoietic progenitor cells. Exp. Hematol. 2002, 30, 990-1000. [CrossRef]

89. Cokic, V.P.; Bhattacharya, B.; Beleslin-Cokic, B.B.; Noguchi, C.T.; Puri, R.K.; Schechter, A.N. JAK-STAT and AKT pathway-coupled genes in erythroid progenitor cells through ontogeny. J. Transl. Med. 2012, 10, 116. [CrossRef] [PubMed]

90. Schmidt, E.K.; Fichelson, S.; Feller, S.M. PI3 kinase is important for Ras, MEK and Erk activation of Epo-stimulated human erythroid progenitors. BMC Biol. 2004, 2, 1-12. [CrossRef] [PubMed]

91. Zhang, J.; Socolovsky, M.; Gross, A.W.; Lodish, H.F. Role of Ras signaling in erythroid differentiation of mouse fetal liver cells: Functional analysis by a flow cytometry based novel culture system. Differentiation 2003, 102, 3938-3946. [CrossRef] [PubMed]

92. Wandzioch, E.; Edling, C.E.; Palmer, R.H.; Carlsson, L.; Hallberg, B. Activation of the MAP kinase pathway by c-Kit is PI-3 kinase dependent in hematopoietic progenitor/stem cell lines. Blood 2004, 104, 51-57. [CrossRef] [PubMed]

93. Jegalian, A.G.; Wu, H. Differential Roles of SOCS Family Members in EpoR Signal Transduction. J. Interf. Cytokine Res. 2002, 22, 853-860. [CrossRef] [PubMed]

94. Sasaki, A.; Yasukawa, H.; Shouda, T.; Kitamura, T.; Dikic, I.; Yoshimura, A. CIS3/SOCS-3 suppresses erythropoietin (EPO) signaling by binding the EPO receptor and JAK2. J. Biol. Chem. 2000, 275, 29338-29347. [CrossRef] [PubMed]

95. Paffett-Lugassy, N.; Hsia, N.; Fraenkel, P.G.; Paw, B.; Leshinsky, I.; Barut, B.; Bahary, N.; Caro, J.; Handin, R.; Zon, L.I. Functional conservation of erythropoietin signaling in zebrafish. Blood 2007, 110, 2718-2726. [CrossRef] [PubMed]

96. Brown, S.; Hu, N.; Hombría, J.C.G. Identification of the first invertebrate interleukin JAK/STAT receptor, the Drosophila gene domeless. Curr. Biol. 2001, 11, 1700-1705. [CrossRef]

97. Liongue, C.; Ward, A.C. Evolution of Class I cytokine receptors. BMC Evol. Biol. 2007, 7, 120. [CrossRef] [PubMed]

98. Ostrowski, D.; Ehrenreich, H.; Heinrich, R. Erythropoietin promotes survival and regeneration of insect neurons in vivo and in vitro. Neuroscience 2011, 188, 95-108. [CrossRef] [PubMed]

99. Miljus, N.; Heibeck, S.; Jarrar, M.; Micke, M.; Ostrowski, D.; Ehrenreich, H.; Heinrich, R. Erythropoietin-mediated protection of insect brain neurons involves JAK and STAT but not PI3K transduction pathways. Neuroscience 2014, 258, 218-227. [CrossRef] [PubMed]

100. Hahn, N.; Knorr, D.Y.; Liebig, J.; Wüstefeld, L.; Peters, K.; Büscher, M.; Bucher, G.; Ehrenreich, H.; Heinrich, R. The Insect Ortholog of the Human Orphan Cytokine Receptor CRLF3 Is a Neuroprotective Erythropoietin Receptor. Front. Mol. Neurosci. 2017, 10, 1-11. [CrossRef] [PubMed]

101. Wu, H.; Lee, S.H.; Gao, J.; Liu, X.; Iruela-Arispe, M.L. Inactivation of erythropoietin leads to defects in cardiac morphogenesis. Development 1999, 126, 3597-3605. [PubMed]

102. Yu, X.; Lin, C.S.; Costantini, F.; Noguchi, C.T. The human erythropoietin receptor gene rescues erythropoiesis and developmental defects in the erythropoietin receptor null mouse. Blood 2001, 98, 475-477. [CrossRef] [PubMed]

103. Juul, S.E.; Yachnis, A.T.; Rojiani, A.M.; Christensen, R.D. Immunohistochemical localization of erythropoietin and its receptor in the developing human brain. Pediatr. Dev. Pathol. 1999, 2, 148-158. [CrossRef] [PubMed]

104. Liu, C.; Shen, K.; Liu, Z.; Noguchi, C.T. Regulated human erythropoietin receptor expression in mouse brain. J. Biol. Chem. 1997, 272, 32395-32400. [CrossRef] [PubMed]

105. Depping, R.; Kawakami, K.; Ocker, H.; Wagner, J.M.; Heringlake, M.; Noetzold, A.; Sievers, H.H.; Wagner, K.F. Expression of the erythropoietin receptor in human heart. J. Thorac. Cardiovasc. Surg. 2005, 130, 877-878. [CrossRef] [PubMed]

106. Zafiriou, M.P.; Noack, C.; Unsoeld, B.; Didie, M.; Pavlova, E.; Fischer, H.J.; Reichardt, H.M.; Bergmann, M.W.; El-Armouche, A.; Zimmermann, W.-H.; et al. Erythropoietin Responsive Cardiomyogenic Cells Contribute to Heart Repair Post Myocardial Infarction. Stem Cells 2014, 2480-2491. [CrossRef] [PubMed] 
107. Westenfelder, C.; Biddle, D.L.; Baranowski, R.L. Human, rat, and mouse kidney cells express functional erythropoietin receptors. Kidney Int. 1999, 55, 808-820. [CrossRef] [PubMed]

108. Lamon, S.; Zacharewicz, E.; Stephens, A.N.; Russell, A.P. EPO-receptor is present in mouse C2C12 and human primary skeletal muscle cells but EPO does not influence myogenesis. Physiol. Rep. 2014, 2, 1-22. [CrossRef] [PubMed]

109. Trincavelli, M.L.; Da Pozzo, E.; Ciampi, O.; Cuboni, S.; Daniele, S.; Abbracchio, M.P.; Martini, C. Regulation of erythropoietin receptor activity in endothelial cells by different erythropoietin (EPO) derivatives: An in vitro study. Int. J. Mol. Sci. 2013, 14, 2258-2281. [CrossRef] [PubMed]

110. Anagnostou, A.; Liu, Z.; Steiner, M.; Chin, K.; Lee, E.S.; Kessimian, N.; Noguchi, C.T. Erythropoietin receptor mRNA expression in human endothelial cells. Proc. Natl. Acad. Sci. USA 1994, 91, 3974-3978. [CrossRef] [PubMed]

111. Knabe, W.; Knerlich, F.; Washausen, S.; Kietzmann, T.; Sirén, A.L.; Brunnett, G.; Kuhn, H.J.; Ehrenreich, H. Expression patterns of erythropoietin and its receptor in the developing midbrain. Anat. Embryol. (Berl.). 2004, 207, 503-512. [CrossRef] [PubMed]

112. Juul, S.E.; Anderson, D.K.; Li, Y.; Christensen, R.D. Erythropoietin and erythropoietin receptor in the developing human central nervous system. Pediatr. Res. 1998, 43, 40-49. [CrossRef] [PubMed]

113. Juul, S.E.; Yachnis, A.T.; Christensen, R.D. Tissue distribution of erythropoietin and erythropoietin receptor in the developing human fetus. Early Hum. Dev. 1998, 52, 235-249. [CrossRef]

114. Tsai, P.T. A Critical Role of Erythropoietin Receptor in Neurogenesis and Post-Stroke Recovery. J. Neurosci. 2006, 26, 1269-1274. [CrossRef] [PubMed]

115. Suzuki, N.; Ohneda, O.; Takahashi, S.; Higuchi, M.; Mukai, H.Y.; Nakahata, T.; Imagawa, S.; Yamamoto, M. Erythroid-specific expression of the erythropoietin receptor rescued its null mutant mice from lethality. Blood 2002, 100, 2279-2288. [CrossRef] [PubMed]

116. Chen, Z.Y.; Asavaritikrai, P.; Prchal, J.T.; Noguchi, C.T. Endogenous erythropoietin signaling is required for normal neural progenitor cell proliferation. J. Biol. Chem. 2007, 282, 25875-25883. [CrossRef] [PubMed]

117. Wenker, S.D.; Chamorro, M.E.; Vota, D.M.; Callero, M.A.; Vittori, D.C.; Nesse, A.B. Differential antiapoptotic effect of erythropoietin on undifferentiated and retinoic acid-differentiated SH-SY5Y cells. J. Cell. Biochem. 2010, 110, 151-161. [CrossRef] [PubMed]

118. Pregi, N.; Vittori, D.; Pérez, G.; Leirós, C.P.; Nesse, A. Effect of erythropoietin on staurosporine-induced apoptosis and differentiation of SH-SY5Y neuroblastoma cells. Biochim. Biophys. Acta 2006, 1763, 238-246. [CrossRef] [PubMed]

119. Sugawa, M.; Sakurai, Y.; Ishikawa-Ieda, Y.; Suzuki, H.; Asou, H. Effects of erythropoietin on glial cell development; oligodendrocyte maturation and astrocyte proliferation. Neurosci. Res. 2002, 44, 391-403. [CrossRef]

120. Sargin, D.; El-Kordi, A.; Agarwal, A.; Müller, M.; Wojcik, S.M.; Hassouna, I.; Sperling, S.; Nave, K.A.; Ehrenreich, H. Expression of constitutively active erythropoietin receptor in pyramidal neurons of cortex and hippocampus boosts higher cognitive functions in mice. BMC Biol. 2011, 9, 27. [CrossRef] [PubMed]

121. Prass, K.; Scharff, A.; Ruscher, K.; Löwl, D.; Muselmann, C.; Victorov, I.; Kapinya, K.; Dirnagl, U.; Meisel, A. Hypoxia-induced stroke tolerance in the mouse is mediated by erythropoietin. Stroke 2003, 34, 1981-1986. [CrossRef] [PubMed]

122. Larpthaveesarp, A.; Georgevits, M.; Ferriero, D.M.; Gonzalez, F.F. Delayed erythropoietin therapy improves histological and behavioral outcomes after transient neonatal stroke. Neurobiol. Dis. 2016, 93, 57-63. [CrossRef] [PubMed]

123. Wang, L.; Zhang, Z.; Wang, Y.; Zhang, R.; Chopp, M. Treatment of stroke with erythropoietin enhances neurogenesis and angiogenesis and improves neurological function in rats. Stroke 2004, 35, 1732-1737. [CrossRef] [PubMed]

124. Brines, M.L.; Ghezzi, P.; Keenan, S.; Agnello, D.; de Lanerolle, N.C.; Cerami, C.; Itri, L.M.; Cerami, A. Erythropoietin crosses the blood-brain barrier to protect against experimental brain injury. Proc. Natl. Acad. Sci. USA 2000, 97, 10526-10531. [CrossRef] [PubMed]

125. McPherson, R.J.; Juul, S.E. Erythropoietin for infants with hypoxic-ischemic encephalopathy. Curr. Opin. Pediatr. 2010, 22, 139-145. [CrossRef] [PubMed] 
126. Aydin, A.; Genc, K.; Akhisaroglu, M.; Yorukoglu, K.; Gokmen, N.; Gonullu, E. Erythropoietin exerts neuroprotective effect in neonatal rat model of hypoxic-ischemic brain injury. Brain Dev. 2003, 25, 494-498. [CrossRef]

127. Kumral, A.; Ozer, E.; Yilmaz, O.; Akhisaroglu, M.; Gokmen, N.; Duman, N.; Ulukus, C.; Genc, S.; Ozkan, H. Neuroprotective effect of erythropoietin on hypoxic-ischemic brain injury in neonatal rats. Biol. Neonate 2003, 83, 224-228. [CrossRef] [PubMed]

128. Elfar, J.C.; Jacobson, J.A.; Puzas, J.E.; Rosier, R.N.; Zuscik, M.J. Erythropoietin accelerates functional recovery after peripheral nerve injury. J. Bone Jt. Surg. Am. 2008, 90, 1644-1653. [CrossRef] [PubMed]

129. Bianchi, R.; Brines, M.; Lauria, G.; Savino, C.; Gilardini, A.; Nicolini, G.; Rodriguez-Menendez, V.; Oggioni, N.; Canta, A.; Penza, P.; et al. Protective effect of erythropoietin and its carbamylated derivative in experimental cisplatin peripheral neurotoxicity. Clin. Cancer Res. 2006, 12, 2607-2612. [CrossRef] [PubMed]

130. Van Der Meer, P.; Lipsic, E.; Henning, R.H.; Boddeus, K.; Van Der Velden, J.; Voors, A.A.; Van Veldhuisen, D.J.; Van Gilst, W.H.; Schoemaker, R.G. Erythropoietin induces neovascularization and improves cardiac function in rats with heart failure after myocardial infarction. J. Am. Coll. Cardiol. 2005, 46, 125-133. [CrossRef] [PubMed]

131. Zhao, C.; Lin, Z.; Luo, Q.; Xia, X.; Yu, X.; Huang, F. Efficacy and Safety of Erythropoietin to Prevent Acute Kidney Injury in Patients With Critical Illness or Perioperative Care: A Systematic Review and Meta-analysis of Randomized Controlled Trials. J. Cardiovasc. Pharmacol. 2015, 65, 593-600. [CrossRef] [PubMed]

132. Sanchis-Gomar, F.; Garcia-Gimenez, J.L.; Pareja-Galeano, H.; Romagnoli, M.; Perez-Quilis, C.; Lippi, G. Erythropoietin and the heart: Physiological effects and the therapeutic perspective. Int. J. Cardiol. 2014, 171, 116-125. [CrossRef] [PubMed]

133. Ehrenreich, H.; Hasselblatt, M.; Dembowski, C.; Cepek, L.; Lewczuk, P.; Stiefel, M.; Rustenbeck, H.H.; Breiter, N.; Jacob, S.; Knerlich, F.; et al. Erythropoietin Therapy for Acute Stroke Is Both Safe and Beneficial. Mol. Med. 2002, 8, 495-505. [PubMed]

134. Ehrenreich, H.; Weissenborn, K.; Prange, H.; Schneider, D.; Weimar, C.; Wartenberg, K.; Schellinger, P.D.; Bohn, M.; Becker, H.; Wegrzyn, M.; et al. Recombinant human erythropoietin in the treatment of acute ischemic stroke. Stroke 2009, 40, e647-e656. [CrossRef] [PubMed]

135. Robertson, C.S.; Hannay, H.J.; Yamal, J.M.; Gopinath, S.; Goodman, J.C.; Tilley, B.C.; Baldwin, A.; Rivera Lara, L.; Saucedo-Crespo, H.; Ahmed, O.; et al. Effect of Erythropoietin and Transfusion Threshold on Neurological Recovery After Traumatic Brain Injury. JAMA 2014, 312, 36. [CrossRef] [PubMed]

136. Nichol, A.; French, C.; Little, L.; Haddad, S.; Presneill, J.; Arabi, Y.; Bailey, M.; Cooper, D.J.; Duranteau, J.; Huet, O.; et al. Erythropoietin in traumatic brain injury (EPO-TBI): A double-blind randomised controlled trial. Lancet 2015, 386, 2499-2506. [CrossRef]

137. Sargin, D.; Friedrichs, H.; El-Kordi, A.; Ehrenreich, H. Erythropoietin as neuroprotective and neuroregenerative treatment strategy: Comprehensive overview of 12 years of preclinical and clinical research. Best Pract. Res. Clin. Anaesthesiol. 2010, 24, 573-594. [CrossRef] [PubMed]

138. Moore, E.; Bellomo, R. Erythropoietin (EPO) in acute kidney injury. Ann. Intensive Care 2011, 1, 1-10. [CrossRef] [PubMed]

139. Wu, Y.W.; Mathur, A.M.; Chang, T.; McKinstry, R.C.; Mulkey, S.B.; Mayock, D.E.; Van Meurs, K.P.; Rogers, E.E.; Gonzalez, F.F.; Comstock, B.A.; et al. High-Dose Erythropoietin and Hypothermia for Hypoxic-Ischemic Encephalopathy: A Phase II Trial. Pediatrics 2016, 137, e20160191. [CrossRef] [PubMed]

140. Elliott, S. Anti-Epo receptor antibodies do not predict Epo receptor expression. Blood 2006, 107, $1892-1895$. [CrossRef] [PubMed]

141. Brown, W.M.; Maxwell, P.; Graham, A.N.J.; Yakkundi, A.; Dunlop, E.A.; Shi, Z.; Johnston, P.G.; Lappin, T.R.J. Erythropoietin receptor expression in non-small cell lung carcinoma: A question of antibody specificity. Stem Cells 2007, 25, 718-722. [CrossRef] [PubMed]

142. Kirkeby, A.; van Beek, J.; Nielsen, J.; Leist, M.; Helboe, L. Functional and immunochemical characterisation of different antibodies against the erythropoietin receptor. J. Neurosci. Methods 2007, 164, 50-58. [CrossRef] [PubMed]

143. Ott, C.; Martens, H.; Hassouna, I.; Oliveira, B.; Erck, C.; Zafeiriou, M.P.; Peteri, U.K.; Hesse, D.; Gerhart, S.; Altas, B.; et al. Widespread Expression of Erythropoietin Receptor in Brain and Its Induction by Injury. Mol. Med. 2015, 21, 803-815. [CrossRef] [PubMed] 
144. Uversky, V.N.; Redwan, E.M. Erythropoietin and co.: Intrinsic structure and functional disorder. Mol. BioSyst. 2017, 13, 56-72. [CrossRef] [PubMed]

145. Soliz, J.; Gassmann, M.; Joseph, V. Soluble erythropoietin receptor is present in the mouse brain and is required for the ventilatory acclimatization to hypoxia. J. Physiol. 2007, 583, 329-336. [CrossRef] [PubMed]

146. Khankin, E.V.; Mutter, W.P.; Tamez, H.; Yuan, H.T.; Karumanchi, S.A.; Thadhani, R. Soluble erythropoietin receptor contributes to erythropoietin resistance in end-stage renal disease. PLOS ONE 2010, 5, e2946. [CrossRef] [PubMed]

147. Yamaji, R.; Okada, T.; Moriya, M.; Naito, M.; Tsuruo, T.; Miyatake, K.; Nakano, Y. Brain capillary endothelial cells express two forms of erythropoietin receptor mRNA. Eur. J. Biochem. 1996, 239, 494-500. [CrossRef] [PubMed]

148. Nakamura, Y.; Komatsu, N.; Nakauchi, H. A Truncated Erythropoietin Receptor That Fails to Prevent Programmed Cell Death of Erythroid Cells. Am. Assoc. Adv. Sci. 1992, 257, 1138-1141. [CrossRef]

149. Shimizu, R.; Komatsu, N.; Miura, Y. Dominant negative effect of a truncated erythropoietin receptor (EPORT) on erythropoietin-induced erythroid differentiation: Possible involvement of EPOR-T in ineffective erythropoiesis of myelodysplastic syndrome. Exp. Hematol. 1999, 27, 229-233. [CrossRef]

150. Marcuzzi, F.; Zucchelli, S.; Bertuzzi, M.; Santoro, C.; Tell, G.; Carninci, P.; Gustincich, S. Isoforms of the Erythropoietin receptor in dopaminergic neurons of the Substantia Nigra. J. Neurochem. 2016, 139, 596-609. [CrossRef] [PubMed]

151. Brines, M. The Therapeutic Potential of Erythropoiesis-Stimulating Agents for Tissue Protection: A Tale of Two Receptors. Blood Purif. 2010, 29, 86-92. [CrossRef] [PubMed]

152. McGraw, K.; List, A. Erythropoietin Receptor Signaling and Lipid Rafts. Vitam. Horm. 2017, 105, 79-100. [PubMed]

153. Chu, C.-Y.; Cheng, C.-H.; Yang, C.-H.; Huang, C.-J. Erythropoietins from teleosts. Cell. Mol. Life Sci. 2008, 65, 3545-3552. [CrossRef] [PubMed]

154. Leist, M.; Ghezzi, P.; Grasso, G.; Bianchi, R.; Villa, P.; Fratelli, M.; Savino, C.; Bianchi, M.; Nielsen, J.; Gerwien, J.; et al. Derivatives of Erythropoietin That Are Tissue Protective However, Not Erythropoietic. Science 2004, 305, 239-242. [CrossRef] [PubMed]

155. Villa, P.; Van Beek, J.; Larsen, A.K.; Gerwien, J.; Christensen, S.; Cerami, A.; Brines, M.; Leist, M.; Ghezzi, P.; Torup, L. Reduced functional deficits, neuroinflammation, and secondary tissue damage after treatment of stroke by nonerythropoietic erythropoietin derivatives. J. Cereb. Blood Flow Metab. 2007, 27, 552-563. [CrossRef] [PubMed]

156. Pankratova, S.; Gu, B.; Kiryushko, D.; Korshunova, I.; Köhler, L.B.; Rathje, M.; Bock, E.; Berezin, V. A new agonist of the erythropoietin receptor, Epobis, induces neurite outgrowth and promotes neuronal survival. J. Neurochem. 2012, 121, 915-923. [CrossRef] [PubMed]

157. Collino, M.; Thiemermann, C.; Cerami, A.; Brines, M. Flipping the molecular switch for innate protection and repair of tissues: Long-lasting effects of a non-erythropoietic small peptide engineered from erythropoietin. Pharmacol. Ther. 2015, 151, 32-40. [CrossRef] [PubMed]

158. Miller, J.L.; Church, T.J.; Leonoudakis, D.; Lariosa-Willingham, K.; Frigon, N.L.; Tettenborn, C.S.; Spencer, J.R.; Punnonen, J. Discovery and Characterization of Nonpeptidyl Agonists of the Tissue-Protective Erythropoietin Receptor. Mol. Pharmacol. 2015, 88, 357-367. [CrossRef] [PubMed]

159. D'Andrea, R.J.; Gonda, T.J. A model for assembly and activation of the GM-CSF, IL-3 and IL-5 receptors: Insights from activated mutants of the common $\beta$ subunit. Exp. Hematol. 2000, 28, 231-243. [CrossRef]

160. Murphy, J.M.; Young, I.G. IL-3, IL-5, and GM-CSF signaling: Crystal structure of the human beta-common receptor. Vitam. Horm. 2006, 74, 1-30. [CrossRef] [PubMed]

161. Bennis, Y.; Sarlon-Bartoli, G.; Guillet, B.; Lucas, L.; Pellegrini, L.; Velly, L.; Blot-Chabaud, M.; Dignat-Georges, F.; Sabatier, F.; Pisano, P. Priming of late endothelial progenitor cells with erythropoietin before transplantation requires the CD131 receptor subunit and enhances their angiogenic potential. J. Thromb. Haemost. 2012, 10, 1914-1928. [CrossRef] [PubMed]

162. Brines, M.; Grasso, G.; Fiordaliso, F.; Sfacteria, A.; Ghezzi, P.; Fratelli, M.; Latini, R.; Xie, Q.W.; Smart, J.; Su-Rick, C.J.; et al. Erythropoietin mediates tissue protection through an erythropoietin and common $\beta$-subunit heteroreceptor. Proc. Natl. Acad. Sci. USA 2004, 101, 14907-14912. [CrossRef] [PubMed]

163. Jubinsky, P.T.; Krijanovski, O.I.; Nathan, D.G.; Tavernier, J.; Sieff, C.A. The $\beta$ Chain of the Interleukin-3 Receptor Functionally Associates with the Erythropoietin Receptor. Blood 1997, 90, 1867-1873. [PubMed] 
164. Hanazono, Y.; Sasaki, K.; Nitta, H.; Yazaki, Y.; Hirai, H. Erythropoietin induces tyrosine phosphorylation of the $\beta$ chain of the GM-CSF receptor. Biochem. Biophys. Res. Commun. 1995, 208, 1060-1066. [CrossRef] [PubMed]

165. Bohr, S.; Patel, S.J.; Vasko, R.; Shen, K.; Iracheta-Vellve, A.; Lee, J.; Bale, S.S.; Chakraborty, N.; Brines, M.; Cerami, A.; et al. Modulation of Cellular Stress Response via the Erythropoietin/ CD131 Heteroreceptor Complex in Mouse Mesenchymal-Derived Cells. J. Mol. Med. 2015, 93, 199-210. [CrossRef] [PubMed]

166. Brines, M.; Cerami, A. The receptor that tames the innate immune response. Mol. Med. 2012, 18, $486-496$. [CrossRef] [PubMed]

167. Chamorro, M.E.; Wenker, S.D.; Vota, D.M.; Vittori, D.C.; Nesse, A.B. Signaling pathways of cell proliferation are involved in the differential effect of erythropoietin and its carbamylated derivative. Biochim. Biophys. Acta 2013, 1833, 1960-1968. [CrossRef] [PubMed]

168. Ding, J.; Wang, J.; Li, Q.Y.; Yu, J.Z.; Ma, C.G.; Wang, X.; Lu, C.Z.; Xiao, B.G. Neuroprotection and CD131/GDNF/AKT Pathway of Carbamylated Erythropoietin in Hypoxic Neurons. Mol. Neurobiol. 2017, 54, 5051-5060. [CrossRef] [PubMed]

169. Swartjes, M.; Morariu, A.; Niesters, M.; Brines, M.; Cerami, A.; Aarts, L.; Dahan, A.; Schartjes, M.; Morariu, A.; Niesters, M.; et al. ARA290, a Peptide Derived from the Tertiary Structure of Erythropoietin, Produces Long-term Relief of Neuropathic Pain. Anesthesiology 2011, 115, 1084-1092. [CrossRef] [PubMed]

170. Khan, A.I.; Coldewey, S.M.; Patel, N.S.; Rogazzo, M.; Collino, M.; Yaqoob, M.M.; Radermacher, P.; Kapoor, A.; Thiemermann, C. Erythropoietin attenuates cardiac dysfunction in experimental sepsis in mice via activation of the $\beta$-common receptor. Dis. Model. Mech. 2013, 6, 1021-1030. [CrossRef] [PubMed]

171. Brines, M.; Patel, N.S.; Villa, P.; Brines, C.; Mennini, T.; De Paola, M.; Erbayraktar, Z.; Erbayraktar, S.; Sepodes, B.; Thiemermann, C.; et al. Nonerythropoietic, tissue-protective peptides derived from the tertiary structure of erythropoietin. Proc. Natl. Acad. Sci. USA 2008, 105, 10925-10930. [CrossRef] [PubMed]

172. Nadam, J.; Navarro, F.; Sanchez, P.; Moulin, C.; Georges, B.; Laglaine, A.; Pequignot, J.M.; Morales, A.; Ryvlin, P.; Bezin, L. Neuroprotective effects of erythropoietin in the rat hippocampus after pilocarpine-induced status epilepticus. Neurobiol. Dis. 2007, 25, 412-426. [CrossRef] [PubMed]

173. Um, M.; Gross, A.W.; Lodish, H.F. A "classical" homodimeric erythropoietin receptor is essential for the antiapoptotic effects of erythropoietin on differentiated neuroblastoma SH-SY5Y and pheochromocytoma PC-12 cells. Cell Signal. 2007, 19, 634-645. [CrossRef] [PubMed]

174. Lisabeth, E.M.; Falivelli, G.; Pasquale, E.B. Eph receptor signaling and ephrins. Cold Spring Harb. Perspect. Biol. 2013, 5. [CrossRef] [PubMed]

175. Kania, A.; Klein, R. Mechanisms of ephrin-Eph signalling in development, physiology and disease. Nat. Rev. Mol. Cell Biol. 2016, 17, 240-256. [CrossRef] [PubMed]

176. Suenobu, S.; Takakura, N.; Inada, T.; Yamada, Y.; Yuasa, H.; Zhang, X.Q.; Sakano, S.; Oike, Y.; Suda, T. A role of EphB4 receptor and its ligand, ephrin-B2, in erythropoiesis. Biochem. Biophys. Res. Commun. 2002, 293, 1124-1131. [CrossRef]

177. Ashton, R.S.; Conway, A.; Pangarkar, C.; Bergen, J.; Lim, K.I.; Shah, P.; Bissell, M.; Schaffer, D.V. Astrocytes regulate adult hippocampal neurogenesis through ephrin-B signaling. Nat. Neurosci. 2012, 15, 1399-1406. [CrossRef] [PubMed]

178. Hamada, K.; Oike, Y.; Ito, Y.; Maekawa, H.; Miyata, K.; Shimomura, T.; Suda, T. Distinct roles of ephrin-B2 forward and EphB4 reverse signaling in endothelial cells. Arterioscler. Thromb. Vasc. Biol. 2003, 23, 190-197. [CrossRef] [PubMed]

179. Steinle, J.J.; Meininger, C.J.; Forough, R.; Wu, G.; Wu, M.H.; Granger, H.J. Eph B4 receptor signaling mediates endothelial cell migration and proliferation via the phosphatidylinositol 3-kinase pathway. J. Biol. Chem. 2002, 277, 43830-43835. [CrossRef] [PubMed]

180. Todd, K.L.; Baker, K.L.; Eastman, M.B.; Kolling, F.W.; Trausch, A.G.; Nelson, C.E.; Conover, J.C. EphA4 Regulates Neuroblast and Astrocyte Organization in a Neurogenic Niche. J. Neurosci. 2017, 37, 3331-3341. [CrossRef] [PubMed]

181. Drescher, U.; Bonhoeffer, F.; Müller, B.K. The Eph family in retinal axon guidance. Curr. Opin. Neurobiol. 1997, 7, 75-80. [CrossRef]

182. Hruska, M.; Dalva, M.B. Ephrin regulation of synapse formation, function and plasticity. Mol. Cell. Neurosci. 2012, 50, 35-44. [CrossRef] [PubMed] 
183. Dines, M.; Grinberg, S.; Vassiliev, M.; Ram, A.; Tamir, T.; Lamprecht, R. The roles of Eph receptors in contextual fear conditioning memory formation. Neurobiol. Learn. Mem. 2015, 124, 62-70. [CrossRef] [PubMed]

184. Blits-Huizinga, C.T.; Nelersa, C.M.; Malhotra, A.; Liebl, D.J. Ephrins and their receptors: Binding versus biology. IUBMB Life 2004, 56, 257-265. [CrossRef] [PubMed]

185. Pradeep, S.; Huang, J.; Mora, E.M.; Nick, A.M.; Choo, M.S.; Wu, S.Y.; Noh, K.; Pecot, C.; Rupaimoole, R.; Stein, M.; et al. Erythropoietin Stimulates Tumor Growth via EphB4 Sunila. Cancer Cell 2015, 28, 610-622. [CrossRef] [PubMed]

186. Liu, T.; Zeng, X.; Sun, F.; Hou, H.; Guan, Y.; Guo, D.; Ai, H.; Wang, W.; Zhang, G. EphB4 Regulates Self-Renewal, Proliferation and Neuronal Differentiation of Human Embryonic Neural Stem Cells in Vitro. Cell. Physiol. Biochem. 2017, 41, 819-834. [CrossRef] [PubMed]

187. Henderson, J.T.; Georgiou, J.; Jia, Z.; Robertson, J.; Elowe, S.; Roder, J.C.; Pawson, T. The receptor tyrosine kinase EphB2 regulates NMDA-dependent synaptic function. Neuron 2001, 32, 1041-1056. [CrossRef]

188. Osredkar, D.; Sall, J.W.; Bickler, P.E.; Ferriero, D.M. Erythropoietin promotes hippocampal neurogenesis in in vitro models of neonatal stroke. Neurobiol. Dis. 2010, 38, 259-265. [CrossRef] [PubMed]

189. Adamcio, B.; Sargin, D.; Stradomska, A.; Medrihan, L.; Gertler, C.; Theis, F.; Zhang, M.; Müller, M.; Hassouna, I.; Hannke, K.; et al. Erythropoietin enhances hippocampal long-term potentiation and memory. BMC Biol. 2008, 6, 1-16. [CrossRef] [PubMed]

190. Boulay, J.L.; O'Shea, J.J.; Paul, W.E. Molecular phylogeny within type I cytokines and their cognate receptors. Immunity 2003, 19, 159-163. [CrossRef]

191. Dang, C.; Gottschling, M.; Manning, K.; O'Currain, E.; Schneider, S.; Sterry, W.; Stockfleth, E.; Nindl, I. Identification of dysregulated genes in cutaneous squamous cell carcinoma. Oncol. Rep. 2006, 16, 513-519. [CrossRef] [PubMed]

192. Yang, F.; Xu, Y.P.; Li, J.; Duan, S.S.; Fu, Y.J.; Zhang, Y.; Zhao, Y.; Qiao, W.T.; Chen, Q.M.; Geng, Y.Q.; et al. Cloning and characterization of a novel intracellular protein $\mathrm{p} 48.2$ that negatively regulates cell cycle progression. Int. J. Biochem. Cell Biol. 2009, 41, 2240-2250. [CrossRef] [PubMed]

193. Mennini, T.; De Paola, M.; Bigini, P.; Mastrotto, C.; Fumagalli, E.; Barbera, S.; Mengozzi, M.; Viviani, B.; Corsini, E.; Marinovich, M.; et al. Nonhematopoietic Erythropoietin Derivates Prevent Motoneuron Degeneration in Vitro and In Vivo. Mol. Med. 2006, 12, 153-160. [CrossRef] [PubMed]

194. Yang, C.; Zhao, T.; Lin, M.; Zhao, Z.; Hu, L.; Jia, Y.; Xue, Y.; Xu, M.; Tang, Q.; Yang, B.; et al. Helix B surface peptide administered after insult of ischemia reperfusion improved renal function, structure and apoptosis through beta common receptor/erythropoietin receptor and PI3K/Akt pathway in a murine model. Exp. Biol. Med. 2013, 238, 111-119. [CrossRef] [PubMed]

195. Nagai, A.; Nakagawa, E.; Choi, H.B.; Hatori, K.; Kobayashi, S.; Kim, S.U. Erythropoietin and erythropoietin receptors in human CNS neurons, astrocytes, microglia, and oligodendrocytes grown in culture. J. Neuropathol. Exp. Neurol. 2001, 60, 386-392. [CrossRef] [PubMed]

196. Foley, L.S.; Fullerton, D.A.; Bennett, D.T.; Freeman, K.A.; Mares, J.; Bell, M.T.; Cleveland, J.C.; Weyant, M.J.; Meng, X.; Puskas, F.; et al. Spinal Cord Ischemia-Reperfusion Injury Induces Erythropoietin Receptor Expression. Ann. Thorac. Surg. 2015, 100, 41-46. [CrossRef] [PubMed]

197. Su, K.H.; Shyue, S.K.; Kou, Y.R.; Ching, L.C.; Chiang, A.N.; Yu, Y.B.; Chen, C.Y.; Pan, C.C.; Lee, T.S. $\beta$ Common receptor integrates the erythropoietin signaling in activation of endothelial nitric oxide synthase. J. Cell. Physiol. 2011, 226, 3330-3339. [CrossRef] [PubMed]

198. Foley, L.S.; Fullerton, D.A.; Mares, J.; Sungelo, M.; Weyant, M.J.; Cleveland, J.C.; Reece, T.B. Erythropoietin's Beta Common Receptor Mediates Neuroprotection in Spinal Cord Neurons. Ann. Thorac. Surg. 2017, 104, 1909-1914. [CrossRef] [PubMed]

(C) 2018 by the authors. Licensee MDPI, Basel, Switzerland. This article is an open access article distributed under the terms and conditions of the Creative Commons Attribution (CC BY) license (http://creativecommons.org/licenses/by/4.0/). 